\title{
The Effectiveness of Blended Training in the Development of Rock-Climbing Athletes in Buleleng Regency in 2021
}

\author{
I Putu Panca Adi ${ }^{1, *}$ Wahjoedi Wahjoedi ${ }^{1}$ Damiati Damiati ${ }^{2}$
}

\author{
${ }^{1}$ Physical Education, Health and Recreation Study Program, Universitas Pendidikan Ganesha, Singaraja, Indonesia \\ ${ }^{2}$ Culinary Arts Vocational Education Study Program, Universitas Pendidikan Ganesha, Singaraja, Indonesia \\ *Corresponding author. Email: drsputupancaadi@gmail.com
}

\begin{abstract}
This research is a type of survey research conducted at FPTI Buleleng Regency, Bali Province. The purpose of this study was to determine the effectiveness of blended training in the development of rock climbing athletes in Buleleng Regency in 2021. The focus of the mapping includes anthropometric aspects and dominant physical components in rock climbing. Data collection was carried out using practical test methods in the field which included tests: Anthropometry, Sit Ups, Push Ups, Stork Stands, Sit and Reach, Sprint Runs, and vertical jumps. The data analysis technique used descriptive statistical analysis with percentages. Based on the results of the study, it can be concluded that in the anthropometric aspect, the athletes of FPTI Buleleng have an average height of $148.15 \mathrm{~cm}$, and weight of $43.67 \mathrm{~kg}$. While in the aspect of the dominant physical component, the balance indicator, 15 athletes $(0.58 \%)$ managed to do the balance test perfectly, and 11 people $(0.42 \%)$ failed to do it perfectly. In the indicators of strength, flexibility, speed, and explosive power, as many as 5 athletes $(19.23 \%)$ were very good, 15 people $(57.69 \%)$ were good, 4 people $(15.38 \%)$ were enough or medium, 2 people ( $7.69 \%)$ less.
\end{abstract}

Keywords: Rock Climbing, Lying Down, Offline, Blended Training.

\section{INTRODUCTION}

In order to make the region proud, both at the regional, national and international levels, achievement sports have a significant and strategic role to be considered carefully. Building sports achievements, of course, is not as easy as it sounds. It needs support from recreational sports and educational sports and is fostered gradually, measurably and sustainably through the stages of massing, seeding and seedling nursery, intensive coaching until achieving top performance.

The interconnection between recreational sports, educational sports and achievement sports is a complete series that synergizes with each other and at the same time a mandate of Law Number 3 of 2005 concerning the National Sports System (UUSKN, Chapter VI Article 17) [1]. Therefore, in the midst of various existing limitations, efforts to develop achievement sports that are in synergy with educational sports and recreational sports must be the determination and commitment of all components of society. It is urgent to be accelerated in real terms and not limited to rhetoric or discourse.
Sports development, in addition to not being supported yet by proper structuring of sports organizations, it also exacerbated by the dark portrait of national sports development, including: 1) the tradition of hijacking athletes from outside the region, 2) incidental development when facing events, 3) there is no touch of science and technology yet, application and implementation of science and technology is still low, 4) does not involve all related professions and stakeholders, 5) limited sports infrastructure and facilities, 6) lack of attention to regeneration and quality of coaches, 7) limited club formation and development, 8) does not have a regular and tiered agenda of championships or competitions, 9) centralized management of individuals or groups of people, and others. The development of Indonesian sports achievements is actually an accumulation and a real portrait of sports development at the regional (provincial and regency/city) level. In addition to being an implication of UUSKN's mandate, sports development in the regions is also expected to be the basis for evaluating the development of regional superior sports and formulating recommendations for the development of leading sports in an integrated manner in the regions. It is known that the region (regency/city government) 
has the responsibility to foster a leading sport at a national and/or international standard (UUSKN, Chapter VIII, Article 34 paragraph 2)[1]. In the sense that districts/cities continuously carry out planning, fostering, developing, implementing standardization, and raising sports resources based on leading sports and other potential local advantages.

In Bali Province, through careful mapping results, nine leading sports in Bali have been established, namely: 1) weightlifting, 2) athletics, 3) sailing, 4) pencak silat, 5) rock climbing, 6) kempo, 7) judo, 8 ) shooting, and 9) billiards ([2][3][4][5]). Thus, regencies/cities in Bali Province are required to sustainably not only carry out planning, coaching, development, standardization, and mobilization of sports resources based on local excellence, but also able to integrate the application of science and technology in leading sports (UUSKN, Chapter VIII, Article 34 paragraph 1)[1] as well as developing and competitions in stages, including starting at school. One of the leading sports in Bali Province which will be the focus of this research is rock climbing among junior/student athletes.

The determination of the sport of rock climbing as the focus of research activities because it is well known that rock climbing is: 1) the 5th leading sport out of 9 leading sports in Bali Province, 2) the special characteristics of the rock climbing sport which is centered on the synergy of physical, technical, mental, and strategic-tactical aspects, 3) the development of rock climbing widely throughout the province of Bali, 4) the contribution of rock climbing sports in Buleleng Regency as an achievement winner or the leading gold medal miner in Buleleng Regency in Porjar Bali, and 5) the openness of the management and trainers in the Achievement Development Sector, FPTI Buleleng who enthusiastically welcomed the research plan at FPTI Buleleng. Based on these potentials and problems, it is considered important to conduct research with the title: The Effectiveness of Blended Training in the Development of the Rock Climbing Athletes of Buleleng Regency in 2021. The effectiveness of the developing is broadly carried out on the anthropometric aspects and the dominant physical components needed in rock climbing sport.

Discussing the development of rock climbing sports, it will not be separated from the sport of mountain climbing and natural rock climbing. Both are embryos of the sport of rock climbing that we know today. In the beginning, before 1988, before people channeled their adventure activities by climbing cliffs, mountain climbing was their adventure event[6].

Mountain climbing is a sport activity that has a significant difference with other sports activities. In sports activities in general, players can only enjoy physical activities and games. While in mountain climbing activities, it is not only enjoying activities and games but also terrain orientation, introduction to habitats around the mountain, flora and fauna, and of course it's adventure. Therefore, various mountains ranging from low, medium to high difficulty levels are accompanied by towering cliffs that are impossible to climb anymore so that they require climbing techniques accompanied by standard climbing equipment and procedures. From this fairly high level of climbing difficulty, the first metamorphosis was born from mountain climbing activities into natural rock climbing activities (natural climbing or rock climbing). Natural rock climbing is recognized as having a higher sporting value, demanding high adrenaline, and having a much higher level of difficulty and potential risk. Therefore, in rock climbing activities or sports, special preparation is needed, both in the physical, mental, technical aspects as well as tactics and strategies.

Just like the special characteristics of athletes/athletes who never know the sense of satisfaction with the achievements they have achieved, the same thing also happens to climbing athletes. After decades of working with natural rock climbing, towards the beginning of 1970, artificial rock climbing was made (artificial or wall climbing), one of which was by Don Robinson at Leeds University, England. Since then, many climbers have switched from natural rock climbing (rock climbing) to artificial rock climbing (wall climbing)[6].

The development of artificial rock climbing (wall climbing) in Indonesia began in 1988 and progressed rapidly, especially in big cities and its peak was the successful formation of a rock climbing organization called the Indonesian Rock Climbing Federation (FPTI)[7]. Since this decade, the sport of rock climbing has begun to show its identity progress and role in the national sports arena. From one competition to the next, one after another followed, both at the regional, national, Southeast Asian, Asian and even international levels.

After going through two metamorphoses, then the sport of rock climbing is now entered as a competitive sport. In the two previous metamorphoses, rock climbing only competes with nature and oneself, so in this third metamorphosis, rock climbing recognizes competitive values directly, both with climbing paths, heights, wind, oneself and other athletes.

As a competitive sport, artificial rock climbing (wall climbing) does not only involve climbers with artificial cliffs being climbed. Rock climbing has developed into a single entity between climbers as athletes, judges, belayers, spectators, and the committee as implementers. They are all bound by boundaries, game/competition rules, and sportsmanship values that apply in the world of sports in order to create sports achievements. 
High achievement is the main goal in every competitive sport, including rock climbing, because it is at this target that the essence of sporting competition among athletes will be seen. Competitive and sportsmanship values will be obtained by athletes if they are able to prepare themselves gradually, measurably and sustainably.

Rock Climbing as the Leading Sport in Bali Province

As previously stated, rock climbing has been in Indonesia since 1998 and has expanded to many big cities, including Denpasar, Bali. The forerunner to the development of rock climbing in the province of Bali (especially in Denpasar) has been sporadical since early 1989 by outdoor activists, especially Nature Lovers Students in several universities, including Udayana University. The peak of the pioneering development of rock climbing sports in Bali Province was when the National Level Artificial Rock Climbing Contest (KPTB) was held in August 1989 by Mapala Wanaprastha Dharma, Udayana University. At that time, the climbing wall facilities were still using conventional materials, namely plywood (multiplex) with a thickness of $18 \mathrm{~mm}$.

Along with the times and demands for weather resistance, in 2000, fiberglass climbing walls were introduced that were resistant to hot and rainy weather. To date, 7 out of 9 regencies/cities in Bali Province have had representative climbing wall facilities with national standards, and we should be grateful that the best climbing wall facilities with national standards in Bali Province to date are owned by FPTI Buleleng

Regency. Which was built in stages in two different locations. The first phase was built in 2005 located in Taman Kota, Singaraja, and the second phase was built in 2015 located at Bhuwana Patra Sports Complex, Singaraja.

From 9 regencies/cities in Bali Province, only Tabanan Regency and Bangli Regency do not have climbing wall facilities, and we all know that currently all FPTI Management, especially FPTI Tabanan Regency are working hard to build climbing wall facilities in 2018 or the first semester of 2019. Of course this is a good news, and at the same time a whip in the effort the gradual, measurable, and sustained reconstruction of rock climbing in the Bali Province. Furthermore, based on the study of predominant sports in the region, rock climbing is the fifth predominant sport of the nine most distinguished sports in the province of Bali. The nine leading sports in the province of Bali include: 1) weight lifting, 2) athletics, 3) sails, 4) lizards, 5) rock climbing, 6) kempo, 7) judo, 8) shooting, and 9) billiards[2][3][5].

The Dominant Physical Compenent of Rock Climbing

The general component (generic) needed in almost every exercise is fitness. In the whole context, then the shifting of modern perspectives in exercise indicates that fitness in whole involves physical fitness and mental fitness (total fitness). In other words, physical fitness (physical fitness) and mental fitness are required to be able to engage in sports effectively.

In physical fitness we know the 11 components of fitness: 1) heart \& lungs resistance, 2) muscular resistance, 3) strength, 4) flexibility, 6) speed, 7) explosiveness, 8) agility, 9) accuracy, 10) reaction speed, 11) coordination.

Based on these components of physical fitness, then implementation in the sports branch varies according to each branch's particular character. There are sports that requires the eleven components adequately balanced, while others demand some of those components, which, in turn, are known as the dominant physical component. Thus, according to the specific characteristics and competition specs, the dominant physical component for rock climbing can be seen at the following table 1 [4].

Based on the previous identification of the physical components by observing and considering: 1) the research subjects are athletes, and 2) the characteristics of grouping athletes into specialization numbers (competition categories) are still tentative and carried Out at the time of concentration of exercise, then the dominant physical component in the rock climbingsport. The focus of this research is including: balance, muscle strength, flexibility, speed, and explosiveness (power). Online training is a training that uses multimedia technology as a means to train. Online training is commonly used as an addition to covering material left

Table 1. Physical Components (Basic and Dominant) in Rock Climbing

\begin{tabular}{|r|l|l|l|}
\hline No & Category & Basic Physical Components & Dominant Physical Component \\
\hline 1 & Boulder & $\begin{array}{l}\text { Strength (muscle \& finger), balance, flexibility \& } \\
\text { explosiveness. }\end{array}$ \\
\hline 2 & Lead & $\begin{array}{l}\text { Strength (muscle \& finger), balance, flexibility \& } \\
\text { explosiveness. }\end{array}$ \\
\hline 3 & Speed Classic & $\begin{array}{l}\text { Endurance (heart-lungs), } \\
\text { movement coordination. }\end{array}$ & Strength (muscle), speed \& explosiveness. \\
\hline
\end{tabular}


behind but is not the same as current conditions.

As we all know, currently online activities (learning and training) are used as the main substitute for teaching or training as a result of the covid-19 pandemic. This is done as a real solution to avoid the spread of Covid-19, so it can be understood if online training becomes the main training menu in the training of athletes in FPTI Buleleng Regency from March 19, 2020 to February 28, 2021. According to Thome[8] online learning is learning that utilizes multimedia technology, video,

Table 2. List of Anthropometric and Balance Data

\begin{tabular}{|c|c|c|c|c|c|}
\hline & \multicolumn{5}{|c|}{ Anthropometry \& Balance Data (Balance) } \\
\hline \multirow[t]{2}{*}{ No } & \multicolumn{2}{|c|}{ Anthropometry } & \multicolumn{3}{|c|}{ Balance } \\
\hline & Height & Weight & Stork & & ategory \\
\hline 1 & 109.8 & 16.1 & $x$ & 0 & Failed \\
\hline 2 & 121.5 & 25.7 & $x$ & 0 & Failed \\
\hline 3 & 120.1 & 23.2 & $\mathrm{X}$ & 0 & Failed \\
\hline 4 & 141.2 & 36.4 & $\mathrm{X}$ & 0 & Failed \\
\hline 5 & 136.2 & 31 & V & 1 & Succesful \\
\hline 6 & 138.5 & 36.9 & V & 1 & Succesful \\
\hline 7 & 147.2 & 38.1 & $\mathrm{X}$ & 0 & Failed \\
\hline 8 & 142.3 & 37.2 & V & 1 & Succesful \\
\hline 9 & 138 & 34.1 & V & 1 & Succesful \\
\hline 10 & 138 & 31.7 & $x$ & 0 & Failed \\
\hline 11 & 153.4 & 46.2 & $x$ & 0 & Failed \\
\hline 12 & 142.5 & 36.3 & V & 1 & Succesful \\
\hline 13 & 142 & 32.8 & V & 1 & Succesful \\
\hline 14 & 162.4 & 51.5 & $x$ & 0 & Failed \\
\hline 15 & 164.2 & 52.7 & $x$ & 0 & Failed \\
\hline 16 & 166.8 & 59.7 & V & 1 & Succesful \\
\hline 17 & 164.6 & 56 & $x$ & 0 & Failed \\
\hline 18 & 154.1 & 43.6 & V & 1 & Succesful \\
\hline 19 & 155.9 & 56.3 & V & 1 & Succesful \\
\hline 20 & 152 & 47.2 & V & 1 & Succesful \\
\hline 21 & 166.8 & 67.8 & V & 1 & Succesful \\
\hline 22 & 165 & 60.2 & V & 1 & Succesful \\
\hline 23 & 146.6 & 42.8 & V & 1 & Succesful \\
\hline 24 & 164.1 & 53.5 & V & 1 & Succesful \\
\hline 25 & 155.1 & 48.5 & V & 1 & Succesful \\
\hline 26 & 163.5 & 70 & $x$ & 0 & Failed \\
\hline $\mathrm{Jml}$ & $3,851.80$ & $1,135.50$ & & 15.00 & \\
\hline Rerata & 148.15 & 43.67 & & 0.58 & \\
\hline
\end{tabular}

virtual classes, animated online text, voicemail, email, video conference, and online streaming video.

Moore, Reference [9] Online learning is learning that uses the internet network with accessibility, connectivity, flexibility, and the ability to bring out various types of learning interactions. Mustofa et al [10]Online learning is a distance education system with a set of teaching methods where there are teaching activities that are carried out separately from learning activities.

Furthermore, based on the results of the FPTI Buleleng Board meeting and coordination with KONI Buleleng Regency and the Covid-19 Countermeasures Task Force of Buleleng Regency, it began today: Tuesday, March 2, 2021 until an undetermined deadline, then the coaching / training of athletes is done through mixed methods (blended training) that is once offline and twice online (3 times per week). This mixed exercise in this study is referred to as blended training.

\section{METHOD}

This study uses a survey research design with a descriptive approach. This research data was collected through tenik field practice test (performance test) conducted by researchers together with testers from among the final-level students of The Penjaskesrek Study Program, POR Department, FOK Undiksha, Achievement Development and Daily Chairman, and monitored directly by the Chairman of FPTI Buleleng.

Data collection begins with anthropometric measurements, then continues with measurements of dominant physical components in rock climbing, which include balance, strength, flexibility, and explosive power. Subsequent research data is analyzed using descriptive statistical analysis techniques by percentage.

\section{RESULT AND DISCUSSION}

The subjects of this study consisted of 26 FPTI Buleleng athletes. Based on the data in Table 2 above it can be concluded that in the anthropometric aspect, FPTI Buleleng athletes have an average height of $148.15 \mathrm{~cm}$, and a weight of $43.67 \mathrm{~kg}$. While in the aspect of the dominant physical component, the balance indicator, 15 people $(0.58 \%)$ athletes managed to perform the balance test (stork stand test) perfectly, and 11 people $(0.42 \%)$ failed to perform perfectly. While in the aspect of the dominant physical component on the indicator of strength, flexibility, speed, and explosive power can be seen in the following table. Based on the data in Table 3, it can be concluded that in terms of dominant physical components, indicators of strength, flexibility, speed, and explosive power can be seen in the following table 4 .

Based on the data in Table 4, it can be stated that the physical components of the domains are as follows. Strength, abdominal muscle strength 18 people/subjects (69\%) had very good abdominal muscle strength, 7 people (27\%) were good, and 1 person (4\%) was enough/medium. Arm muscle strength, 19 people $(73 \%)$ 
had very good arm muscle strength, 5 people (19\%) were good, and 2 people $(8 \%)$ were moderate. Flexibility, 7 people $(27 \%)$ had very good flexibility, 6 people $(23 \%)$ were good, 3 people (12\%) were moderate, 7 people $(27 \%)$ were poor, and 3 people $(12 \%)$ were very poor. Speed, 4 people $(15 \%)$ have very good speed, 7 people $(27 \%)$ are good, and 11 people
$(42 \%)$ are moderate, 3 people $(12 \%)$ are poor, and 1 person $(4 \%)$ is very poor, Power explosive, 4 people (15\%) had very good explosive power, 7 people $(27 \%)$ were good, 11 people $(42 \%)$ were moderate, 3 people $(12 \%)$ were poor, and 1 person $(4 \%)$ was very poor. The overall dominant physical component category on the four indicators can be seen in the following table.

Table 3. Categories of Dominant Physical Components Strength, Flexibility, Speed, and Explosive Power of FPTI Buleleng Athletes

\begin{tabular}{|c|c|c|c|c|c|c|c|c|c|c|c|c|}
\hline \multirow[t]{3}{*}{ Number } & \multicolumn{10}{|c|}{ Strength, Flexibility, Speed, and Explosive Power Data } & \multicolumn{2}{|c|}{ Category } \\
\hline & \multicolumn{2}{|c|}{ Sit Up } & \multicolumn{2}{|c|}{ Push Up } & \multicolumn{2}{|c|}{ Sit \& Reach } & \multicolumn{2}{|c|}{ Sprint } & \multicolumn{2}{|c|}{ Vertical Jump } & \multirow[t]{2}{*}{ Total } & \multirow[t]{2}{*}{ Category } \\
\hline & Score & Category & Score & Category & Score & Category & Score & Category & Score & Category & & \\
\hline 1 & 14 & 4 & 10 & 3 & 7.5 & 2 & 8.91 & 1 & 23 & 3 & 13 & L \\
\hline 2 & 17 & 5 & 13 & 4 & 13.2 & 5 & 7.62 & 3 & 22 & 3 & 20 & $G$ \\
\hline 3 & 18 & 5 & 17 & 5 & 13 & 5 & 6.92 & 3 & 28 & 3 & 21 & $G$ \\
\hline 4 & 12 & 3 & 18 & 4 & 3.2 & 1 & 8.49 & 2 & 34 & 3 & 13 & L \\
\hline 5 & 21 & 4 & 29 & 5 & 8.3 & 2 & 7.05 & 3 & 22 & 1 & 15 & $\mathrm{E} / \mathrm{M}$ \\
\hline 6 & 24 & 5 & 23 & 5 & 11 & 4 & 6.8 & 5 & 51 & 5 & 24 & VG \\
\hline 7 & 18 & 4 & 26 & 5 & 16.2 & 5 & 8.15 & 3 & 43 & 5 & 22 & VG \\
\hline 8 & 25 & 5 & 21 & 4 & 10.4 & 3 & 7.18 & 3 & 43 & 4 & 19 & G \\
\hline 9 & 21 & 4 & 16 & 3 & 3 & 1 & 7.52 & 3 & 39 & 4 & 15 & $E / M$ \\
\hline 10 & 21 & 4 & 20 & 4 & 18 & 5 & 6.98 & 3 & 45 & 4 & 20 & $G$ \\
\hline 11 & 18 & 4 & 27 & 5 & 13.1 & 4 & 6.82 & 4 & 40 & 4 & 21 & $G$ \\
\hline 12 & 17 & 4 & 19 & 4 & 14.3 & 4 & 7.52 & 4 & 34 & 4 & 20 & $G$ \\
\hline 13 & 61 & 5 & 42 & 5 & 13.7 & 2 & 8.42 & 3 & 40 & 2 & 17 & $E / M$ \\
\hline 14 & 57 & 5 & 49 & 5 & 13.2 & 2 & 6.71 & 5 & 53 & 4 & 21 & $G$ \\
\hline 15 & 54 & 5 & 41 & 5 & 16.5 & 3 & 7.06 & 4 & 50 & 3 & 20 & G \\
\hline 16 & 55 & 5 & 44 & 5 & 18 & 4 & 7.2 & 4 & 62 & 4 & 22 & VG \\
\hline 17 & 65 & 5 & 55 & 5 & 13.8 & 2 & 7.14 & 4 & 57 & 4 & 20 & G \\
\hline 18 & 50 & 5 & 40 & 5 & 23.2 & 5 & 7.32 & 5 & 46 & 4 & 24 & VG \\
\hline 19 & 54 & 5 & 45 & 5 & 21.4 & 4 & 9.09 & 3 & 39 & 3 & 20 & G \\
\hline 20 & 55 & 5 & 50 & 5 & 22.7 & 5 & 7.52 & 5 & 44 & 4 & 24 & VG \\
\hline 21 & 70 & 5 & 40 & 5 & 13 & 2 & 7.9 & 3 & 50 & 3 & 18 & G \\
\hline 22 & 65 & 5 & 45 & 5 & 12.3 & 2 & 7.23 & 4 & 59 & 4 & 20 & $G$ \\
\hline 23 & 52 & 5 & 45 & 5 & 25.3 & 4 & 10.32 & 3 & 35 & 3 & 20 & G \\
\hline 24 & 51 & 5 & 49 & 5 & 20.4 & 3 & 8.27 & 4 & 62 & 4 & 21 & G \\
\hline 25 & 50 & 5 & 43 & 5 & 22 & 3 & 11.75 & 2 & 38 & 3 & 18 & G \\
\hline 26 & 42 & 5 & 35 & 5 & 10.3 & 1 & 11.48 & 2 & 33 & 3 & 16 & $E / M$ \\
\hline TOTAL & 1007 & 121 & 862 & 121 & 377 & 83 & 207.4 & 88 & 1092 & 91 & 504 & \\
\hline AVERAGE & 38.73 & 4.65 & 33.15 & 4.65 & 14.50 & 3.19 & 7.98 & 3.38 & 42.00 & 3.50 & 19.38 & \\
\hline
\end{tabular}


Table 4. Categories of Dominant Physical Components of each Indicator (Strength, Flexibility, Speed, and Explosive Power) FPTI Buleleng Athletes

\begin{tabular}{|c|c|c|c|c|c|c|c|c|c|c|c|}
\hline \multirow{3}{*}{ Number } & \multirow{3}{*}{ Category } & \multicolumn{4}{|c|}{ Strength } & \multirow{2}{*}{\multicolumn{2}{|c|}{ Flexibility }} & \multirow{2}{*}{\multicolumn{2}{|c|}{ Speed }} & \multirow{2}{*}{\multicolumn{2}{|c|}{$\begin{array}{c}\text { Explosion } \\
\text { Power }\end{array}$}} \\
\hline & & \multicolumn{2}{|c|}{$\begin{array}{l}\text { Abdominal } \\
\text { Muscles }\end{array}$} & \multicolumn{2}{|c|}{$\begin{array}{c}\text { Arm } \\
\text { Muscle }\end{array}$} & & & & & & \\
\hline & & Ttl & $\%$ & $\mathrm{Ttl}$ & $\%$ & $\mathrm{Ttl}$ & $\%$ & Ttl & $\%$ & Ttl & $\%$ \\
\hline 1 & Very Good (VG) & 18 & 69 & 19 & 73 & 7 & 27 & 4 & 15 & 4 & 15 \\
\hline 2 & $\operatorname{Good}(\mathrm{G})$ & 7 & 27 & 5 & 19 & 6 & 23 & 7 & 27 & 7 & 27 \\
\hline 3 & Enough/Medium (E/M) & 1 & 4 & 2 & 8 & 3 & 12 & 11 & 42 & 11 & 42 \\
\hline 4 & Less (L) & 0 & 0 & 0 & 0 & 7 & 27 & 3 & 12 & 3 & 12 \\
\hline 5 & Very Less (VL) & 0 & 0 & 0 & 0 & 3 & 12 & 1 & 4 & 1 & 4 \\
\hline Total & 26 & 100 & 26 & 100 & 26 & 100 & 26 & 100 & 26 & 100 & \\
\hline
\end{tabular}

Table 5. Categories of Dominant Physical Components Combined Indicators (Strength, Flexibility, Speed, and Explosive Power) FPTI Buleleng Athletes

\begin{tabular}{|c|l|c|c|}
\hline Number & \multicolumn{1}{|c|}{ Category } & Ttl & $\%$ \\
\hline 1 & Very Good (VG) & 5 & 19.23 \\
\hline 2 & Good (G) & 15 & 57.69 \\
\hline 3 & Enough/Medium (E/M) & 4 & 15.38 \\
\hline 4 & Less (L) & 2 & 7.69 \\
\hline 5 & Very Less (VL) & 0 & 0.00 \\
\hline Total & 26 & 100 & \\
\hline
\end{tabular}

Based on the data in Table 4, it can be stated that the physical components of the domains are as follows. Strength, abdominal muscle strength 18 people/subjects (69\%) had very good abdominal muscle strength, 7 people (27\%) were good, and 1 person (4\%) was enough/medium. Arm muscle strength, 19 people (73\%) had very good arm muscle strength, 5 people $(19 \%)$ were good, and 2 people $(8 \%)$ were moderate. Flexibility, 7 people $(27 \%)$ had very good flexibility, 6 people $(23 \%)$ were good, 3 people (12\%) were moderate, 7 people $(27 \%)$ were poor, and 3 people $(12 \%)$ were very poor. Speed, 4 people $(15 \%)$ have very good speed, 7 people $(27 \%)$ are good, and 11 people $(42 \%)$ are moderate, 3 people $(12 \%)$ are poor, and 1 person $(4 \%)$ is very poor, Power explosive, 4 people (15\%) had very good explosive power, 7 people $(27 \%)$ were good, 11 people $(42 \%)$ were moderate, 3 people $(12 \%)$ were poor, and 1 person $(4 \%)$ was very poor. The overall dominant physical component category on the four indicators can be seen in the following table.

Based on the data in Table 5, it can be stated that in the dominant physical component in the combined indicators of strength, flexibility, speed, and explosive power, as many as 5 athletes $(19.23 \%)$ were very good, 15 people $(57.69 \%)$ were good, 4 people $(15.38 \%)$ are moderate or moderate, 2 people $(7.69 \%)$ are less. While in the aspect of the dominant physical component, the indicator of balance, 15 athletes $(0.58 \%)$ succeeded in carrying out a balance test (Stork Stand Test), and 11 people $(0.42 \%)$ failed.

The mapping profile of the practice test results, both separately and as a whole, is still heterogeneous and on some indicators the results are less than optimal, of course, it can be understood as a concrete impact of not maximizing practice. In the sense that the training for FPTI Buleleng athletes is carried out in a blended manner, which is a mixture of offline and online training.

Offline training as per the fixed schedule for the Binpres Division of FPTI Buleleng is carried out 3 times a week, namely: Tuesday afternoon, Thursday afternoon, and Sunday. The training was carried out in 2 (two) venues owned by FPTI Buleleng, namely at the Bhuwana Patra Field Complex and at Singaraja City Park. When facing certain events, the practice frequency was increased up to 5 times a week. In fact, to improve the physical condition and develop a variety of athlete skills, as well as avoid training saturation, athletes are carried out various exercises through rock climbing and back to nature such as trekking, fartlek, and others. Furthermore, the exercises are carried out online 
(independently at home) on the same day according to the training program sent based on the FPTI Buleleng Athlete's WA Group by the Coach Team.

During the Covid-19 pandemic, based on policies from the Buleleng FPTI Management and Buleleng Regency KONI in order to prevent and avoid the massive spread of Covid-19, since Thursday, March 19, 2020, the "Practicing from Home (BDR)" program has been set. Even though BDR is still training intensively and independently 3 times a week (Tuesday, Thursday and Sunday). The implementation of BDR still refers to the training program that has been prepared by the FPTI Buleleng Coaching Team, adheres to health protocols and the implementation of the exercise remains monitored through direct reporting by each athlete for each exercise through photos and videos, as well as mentoring and supervision carried out by the FPTI Buleleng Achievement Development Division.The photos and videos are very well documented at FPTI Buleleng and can be accessed by various related parties, such as Disdikpora and KONI of Buleleng Regency, Pengprov FPTI Bali, Athlete Parents Association (IOA FPTI Buleleng) as well as for research purposes, and others.

Based on real facts on the ground, if the training conditions were carried out in full, the results would be very different. Aswell known to the general public, and based on the results of the monitoring and evaluation conducted centrally by KONI and the Management of FPTI Buleleng, the results were dominantly very good. So that with the planned training, and carried out in stages, measurably and sustainably, the Buleleng FPTI successfully gave birth to the First Winner of PON XX Papua, from September 28 to October 8, 2021 on behalf of the female athlete: Made Desak Rita Kusuma Dewi. The athlete was even able to rank IV in the Spirt Climbing World Cup in Villars Switzerland, on July 2, 2021.

Right after PON XX Papua, precisely on October 11, 2021, the proud rock climbing hero of Buleleng Regency, Bali Province and even to Indonesia immediately rejoined the Long-Term Rock Climbing National Training Center which is projected to drop in various single events such as the IFSC World Cup and multievents, both the Sea Games, Asian Games and Olympic Games.

\section{CONCLUSION}

Based on the description of the data and the results of the study, it can be concluded that in the anthropometric aspect, the athletes of FPTI Buleleng have an average height of $148.15 \mathrm{~cm}$ and weight of $43.67 \mathrm{~kg}$. While in the aspect of the dominant physical component, the indicator of balance, 15 athletes $(0.58 \%)$ managed to do a perfect balance test (Stork Stand Test), and 11 people $(0.42 \%)$ failed to do it perfectly. In the indicators of strength, flexibility, speed, and explosive power, as many as 5 athletes $(19.23 \%)$ were very good, 15 people $(57.69 \%)$ were good, 4 people $(15.38 \%)$ were enough/medium, 2 people $(7.69 \%)$ less.

\section{REFERENCES}

[1] Law of the Republic of Indonesia Number 3 of 2005, Concerning the National Sports System. Jakarta:Biro Hukum Kemenpora, 2005.

[2] Wahjoedi, Mapping of Bali's Leaning Sports Branch. Jakarta:Kemenpora RI, 2006.

[3] Kemenpora, Mapping of National Leading Sports Branches. Jakarta:Asdep Iptekor, 2007.

[4] Wahjoedi, Acceleration of Achievement of FPTI Buleleng, Presented. Singaraja, 18 September 2019, 2019.

[5] Wahjoedi, I. P. P. Adi, and W. Danardani, Development of Bali's Leaning Sports Branch in Denpasar City Facing Porpov IX Year 2009. Singaraja:Undiksha, 2009.

[6] E. Sanoesi, New Phenoena Rock Climbing a Competitive Sport. Jakarta:FPTI Pusat, 1996.

[7] FPTI Buleleng Regency and LPPM Undiksha, "Competition Rules Jakarta:Competition Field," in Collection of Training Materials for the Application of Sports Science and Technology in Development of Rock Climbing Sports in Buleleng Regency, Singaraja: Panpel, 2017.

[8] M. T. Yanti, E. Kuntarto, and A. R. Kurniawan, "Pemanfaatan Portal Rumah Belajar Kemendikbud sebagai Model Pembelajaran Daring di Sekolah Dasar," Adi Widya J. Pendidik. Dasar, vol. 10, no. 1, pp. 61-68, 2020.

[9] A. Sadikin and A. Hamidah, "Online Learning in the Middle of the Covid-19 Pandemic," BIODIKJurnal Ilm. Pendidik. Biol., vol. 6, no. 2, pp. 214-224, 2020.

[10] Y. Fitriyani, I. Fauzi, and M. Z. Sari, "Motivasi Belajar Mahasiswa pada Pembelajaran Daring Selama Pandemik Covid-19," J. Kependidikan, vol. 6 , no. 2, pp. 165-175, 2020 